\title{
PERANCANGAN BOARD GAME SEBAGAI MEDIA PENUNJANG UNTUK MENINGKATKAN MINAT KEGIATAN EKSTRAKURIKULER PRAMUKA PENGGALANG SISWA SEKOLAH DASAR
}

\author{
Rahmat Kurniawan ${ }^{1,}$ Abdu Ghafar Razaq ${ }^{2}$, Evy Poerbaningtyas ${ }^{3}$ \\ Desain Komunikasi Visual \\ Sekolah Tinggi Informatika dan Komputer Indonesia Malang \\ corresponding author: Rahmat Kurniawan, rahmat@stiki.ac.id, Malang, Indonesia
}

\begin{abstract}
Abstrak. Pramuka adalah sebuah kegiatan pembentukan kedisiplinan, akhlak, watak, dan pembinaan mental dengan proses pembelajaran di luar lingkungan sekolah dan di luar lingkungan keluarga yang dikemas secara menarik dan menyenangkan yang dilakukan di alam terbuka. Materi pembelajaran pramuka terdapat dua macam, yaitu pembelajaran pengetahuan dan pembelajaran teknik kepramukaan. Saat pembelajaran, terdapat siswa yang mampu menangkap materi dengan mudah dan ada yang sulit dalam menangkap materi. Maka dari itu diharapkan siswa yang mampu menangkap materi yang diajarkan bisa mengajarkan kepada siswa yang belum mampu menangkap materi yang diajarkan. Hasil observasi menunjukkan terdapat sedikit siswa yang kurang minat dalam mengikuti kegiatan pramuka dengan ditunjukkan sikap yang kurang perhatian terhadap materi yang disampaikan. Dengan masalah tersebut, maka peneliti membuat media penunjang melalui board game yang berjudul "Pramuka Adventure". Permainan ini dibuat dengan mengacu pada buku saku pramuka. Teknik pengumpulan data yang dilakukan berupa wawancara kepada pembina pramuka, membagikan kuesioner kepada siswa sekolah dasar kelas 5 dan 6 dan observasi dengan hadir langsung di lapangan.
\end{abstract}

Kata Kunci: Board Game, Pramuka, Penggalang, Sekolah Dasar, Permainan

\begin{abstract}
Scout is a disciplinary, morals, character and mental developer activities outside the school and family environment where the learning process packed in an interesting and fun way helded in an open nature. There are 2 types of scout learning materials which is scouting knowledge and scouting techniques. In learning process, there are students that be able to understand the learning materials and some can not understand the learning materials. Therefore students who are able to capture the materials that being taught can help to teach the others who unable to understand the learning materials. The observation result shows that there are few students who have less interest in participating in scouting activities by showing lack of attention to the presented learning materials. Based on that problem, we make a media support using board game which titled "Pramuka Adventure". This game designed based on the scout's pocket book. The data technique was collected by interviewing the scout coaches, questionnaire to the 5th and 6th grade of elementary school students and field observation.
\end{abstract}

Keywords: Board Game, Scout, Raiser, Elementary School, Games 


\section{Pendahuluan}

Pramuka adalah sebuah kegiatan pembentukan kedisiplinan, akhlak, watak, dan pembinaan mental dengan proses pembelajaran di luar lingkungan sekolah dan di luar lingkungan keluarga yang dikemas secara menarik dan menyenangkan yang dilakukan di alam terbuka (Firmansyah 2014). Pramuka saat ini menjadi ekstrakurikuler wajib di sekolah semenjak Kurikulum 2013 berlaku dan dasar legalitasnya jelas dengan adanya Undang - Undang yang mengatur tentang Gerakan Pramuka.

Materi pembelajaran pramuka terdapat dua macam, yaitu pembelajaran pengetahuan dan pembelajaran teknik. Materi pembelajaran pengetahuan pramuka berisikan pemahaman yang akan dibawa dalam kepramukaan, meliputi: arti, sejarah, tujuan, dan fnngsi pramuka. Sedangkan dalam pembelajaran teknik pramuka berisikan ketrampilan dasar yang menjadi bagian dari pramuka, meliputi: tali temali, sandi, baris - berbaris dan P3K (Pertolongan Pertama pada Kecelakaan).

SD Negeri Bumiayu 2 Malang adalah salah satu sekolah di mana terdapat ekstrakurikuler pramuka yang diwajibkan. Sekolah ini beralamat di jalan Lembayung, Bumiayu kota Malang. Sekolah tersebut merupakan salah satu sekolah yang aktif mengikuti kegiatan Green School Festival yang dituntut untuk banyak dilakukan penghijauan, tidak ada sampah plastik, dan memiliki ekstrakurikuler yang aktif seperti pramuka. Kegiatan pramuka di sekolah tersebut diwajibkan dan diberlakukan kepada siswa mulai dari kelas 3 hingga kelas 6.

Arif Susanto sebagai salah satu Pembina pramuka SD Negeri Bumiayu 2 Malang, dari hasil wawancara beliau berpendapat bahwa karakteristik setiap siswa berbeda. Ada siswa yang mampu menangkap materi yang sudah diajarkan dan ada yang belum menangkap materi keseluruhan yang sudah diajarkan. Maka dari itu diharapkan siswa yang mampu menangkap materi yang diajarkan bisa mengajarkan kepada siswa yang belum mampu menangkap materi yang diajarkan.

Hasil kuesioner menunjukkan, siswa mengetahui tentang pramuka. Banyak siswa yang senang mengikuti pramuka dan hanya sedikit siswa yang tidak senang mengikuti pramuka. Proses belajar - mengajar pramuka pada sekolah tersebut disenangi oleh banyak siswa dan terdapat sedikit siswa yang biasa saja mengikuti kegiatan pramuka tersebut. Selain dari data kuesioner, hasil observasi menunjukkan bahwa terdapat sedikit siswa tingkatan Penggalang SD Negeri Bumiayu 2 Malang yang kurang minat dengan kegiatan pramuka dengan ditunjukkannya sikap yang kurang memperhatikan materi yang disampaikan oleh pembina pramuka.

Mengajarkan pramuka kepada siswa belum cukup hanya dengan lisan dan dari buku modul saja. Tetapi juga harus didampingi dengan media penunjang pembelajaran siswa agar bisa lebih dimengerti, dipahami, dan diminati oleh siswa tersebut. Pembina pramuka juga belum mempunyai media untuk digunakan sebagai pembelajaran yang bisa membuat siswa belajar lebih giat dan menyenangkan. Sekolah mempunyai media berupa proyektor yang digunakan untuk menampilkan materi pembelajaran. Dengan adanya media pembelajaran yang mendukung, maka siswa bisa belajar lebih menyenangkan dan bisa menangkap materi - materi yang disampaikan.

Anak sekolah dasar adalah anak yang berusia antara $6-12$ tahun atau biasa disebut periode intelektual (Jatmika 2005). Pada masa ini anak mengalami pertumbuhan fisik dan psikologis. Anak akan belajar untuk mengenali lingkungannya baik lingkungan keluarga, masyarakat, ataupun sekolah. Menurut Burhaein (2017), karakteristik anak sekolah dasar terdapat berbagai macam, yaitu: anak usia SD senang bermain, anak usia SD senang bergerak, anak usia SD senang bekerja dalam kelompok, dan anak usia SD senang merasakan atau melakukan atau memperagakan sesuatu secara langsung. 
Permainan edukasi adalah permainan yang dikemas untuk meningkatkan konsentrasi dan merangsang daya pikir pada pemain. Pemanfaatan permainan edukasi pada proses belajar mengajar merupakan salah satu cara yang tepat, karena dalam permainan tersebut terdapat media visual yang memiliki kelebihan dari media visual lainnya. Permainan edukasi ini bertujuan untuk dapat mengatasi masalah pembelajaran dalam meningkatkan minat dalam belajar, membantu perkembangan, kecerdasan, dan meningkatkan kemampuan anak dalam proses belajar (Rahman and Tresnawati 2016). Menurut Mubarok $(2008,11)$, permainan bagi anak bukan hanya untuk kesenangan, akan tetapi sebagai kebutuhan juga. Lewat bermain, maka anak secara tidak sadar mengasah bakat terpendamnya. Contoh dari permainan edukasi ini adalah board game.

Board game menurut Sugianto, Prayanto, and Yudani (2015) adalah jenis permainan di mana alat-alat atau bagian-bagian permainan ditempatkan, dipindahkan, atau digerakkan pada permukaan yang telah ditandai atau dibagi - bagi menurut seperangkat aturan. Board game dipilih sebagai media utama permainan edukasi karena board game memiliki beberapa kelebihan yang tidak ada pada jenis game lainnya seperti aturan pada permainan yang membuat anak belajar menaati aturan yang ada dan belajar kedisiplinan, memicu interaksi sosial antar pemain, melatih anak bagaimana menjalani kehidupan bermasyarakat, dan lain sebagainya (Jordi, Faisal, and Ahdi 2017). Board game memiliki beberapa jenis, masing - masing memiliki cara bermain dan aturan yang berbeda. Berikut adalah beberapa jenis menurut (Ziz 2015), antara lain: Classic Board Game, Euro-Styles Games, Deck-Building Games, Abstract Strategy Games, Strategy Games, dan Card-Based Strategy Games. Pada perancangan ini menggunakan jenis Classic Board Game karena dalam permainan ini juga menggantungkan pada keberuntungan dan dimainkan bersama-sama agar menjadi menarik.

\section{Metode}

Perancangan board game ini memiliki alur perancangan yang merujuk pada metode perancangan Sadjiman Ebdi Sanyoto, terdapat tahapan yang telah disesuaikan dengan perancangan board game pramuka untuk tingkatan penggalang siswa sekolah dasar. Metode perancangan oleh Sanyoto (2006) ini dimodifikasi agar lebih menyesuaikan dengan kebutuhan perancangan board game pramuka. Tahapan yang disesuaikan terdapat pada tahap, data lapangan, data pustaka, perencanaan media, perencanaan kreatif, dan konsep tata desain. Berikut adalah tahapan yang telah disesuaikan.

\section{Tahapan Perancangan}

Data dalam perancangan diperoleh melalui data lapangan dan data pustaka. Data lapangan diperoleh dari data primer yang dilakukan oleh peneliti dengan cara wawancara dengan pembina pramuka SD Bumiayu 2, observasi secara langsung kegiatan belajar mengajar pramuka, dan menyebar kuesioner kepada siswa kelas 5 dan 6 yang merupakan siswa pramuka tingkatan Penggalang. Data pustaka diperoleh dari data sekunder yang dilakukan oleh penulis yang diperoleh dari jurnal tentang penelitian yang relevan, internet, dan buku. Perancangan board game pramuka ini memuat materi - materi tentang pramuka yang akan dijadikan konten dalam permainan. Materi tersebut merujuk pada buku Saku pramuka.

Perencanaan kreatif adalah perencanaan yang meliputi hal - hal yang berkaitan dengan gambaran dan pesan yang disampaikan dalam perancangan. Dalam perencanaan kreatif tersebut terdapat beberapa materi, yaitu tujuan kreatif, strategi kreatif, program kreatif, dan biaya kreatif. Perancangan board game pramuka ini hanya mengambil beberapa materi, yaitu tujuan kreatif dan strategi kreatif. 
Konsep tata desain terdapat proses visualisasi dari perancangan board game pramuka untuk siswa tingkatan penggalang sekolah dasar. Dalam konsep tata desain sendiri terdapat beberapa materi. Namun dalam perancangan board game pramuka ini materinya telah disesuaikan, yaitu concepting phase, design phase, dan prototyping phase. Dalam concepting phase, akan menentukan elemen game berdasarkan analisis data yang sudah dilakukan sebelumnya, antara lain tujuan dari game, aturan dasar permainan, mekanisme permainan, serta cerita permainan. Dalam design phase dilakukan pembuatan prototype agar dapat mengetahui kekurangan dari cara bermain dan juga tampilan (Elianta, Prestiliano, and Setiawan 2019).

Teknik pengumpulan data dilakukan dengan 1) Observasi adalah teknik pengumpulan data dengan cara mengamati dan mencatat secara sistematik unsur-unsur yang tampak dalam suatu objek penelitian Nawawi dan Martini dalam Sugianto, Prayanto, and Yudani $(2015,2)$ wawancara adalah teknik pengumpulan data dengan cara menanyakan sesuatu kepada seseorang yang menjadi informan dengan bercakap-cakap secara tatap muka Afifudin dan Saebani dalam Sugianto, Prayanto, and Yudani $(2015,3)$. Kuesioner adalah sebagai sekumpulan pertanyaan yang digunakan untuk memperoleh informasi dan responden terkait dengan materi penelitian Arikunto dalam Nugroho (2018). Analisis data adalah cara pengolahan data untuk dijadikan informasi yang bisa dipahami dan bermanfaat dengan tujuan untuk menyelesaikan suatu masalah. Dalam perancangan board game sebagai media penunjang ekstrakurikuler pramuka ini peneliti menggunakan metode analisa $5 \mathrm{~W}+1 \mathrm{H}$.

\section{Hasil dan Pembahasan}

Perancangan ini telah menunjuk salah satu perancangan dalam artikel sebelumnya untuk dijadikan perbandingan. Artikel tersebut berjudul "Perancangan Board Game sebagai Media Pembelajaran Keselamatan Berkendara untuk Remaja dengan Mekanik Dice Rolling" (Elianta, Prestiliano, and Setiawan 2019). Boardgame pada jurnal tersebut memiliki nama yaitu "Mudik Yuk". Artikel Board game "Mudik Yuk" membahas tentang pembelajaran keselamatan dalam berkendara pada remaja. Dalam permainan ini, menceritakan pemain pulang menuju kota asal atau kampung halaman masing-masing dengan memperhatikan keselamatan berkendara dan persyaratan yang ada.

Perancangan board game pramuka ini membahas tentang pembelajaran materi kepramukaan yang dikemas dengan tema petualangan. Permainan board game pramuka ini menceritakan pemain yang sedang berada di hutan menuju tempat tujuan. Selama dalam perjalanan, pemain akan menemui beberapa rintangan yang berisikan materi-materi pramuka.

Kedua artikel tersebut memiliki pembahasan yang sama yaitu tentang pembelajaran. Dalam pembelajaran tersebut bertujuan membuat target audience mengerti pesan yang akan disampaikan oleh perancang. Pesan tersebut dikemas secara menarik dengan permainan board game sehingga para target audience mudah memahami pesan yang disampaikan dan materi yang dibawakan.

\section{Analisis Data}

Analisis data dalam perancangan board game sebagai media penunjang ekstrakurikuler pramuka ini metode analisa $5 \mathrm{~W}+1 \mathrm{H}$ (What, Where, When, Who, Why, How). Pramuka saat ini diwajibkan dengan adanya Undang-Undang yang mengatur tentang kewajiban mengikuti kegiatan pramuka terutama sekolah dasar. SD Bumiayu 2 adalah salah satu sekolah dasar yang menerapkan wajib mengikuti kegiatan ekstrakurikuler pramuka. Dari hasil observasi, terdapat sedikit siswa yang kurang minat dalam kegiatan wajib pramuka. Hal ini ditunjukkan dengan sikap 
siswa yang bergurau selama pemberian materi dan terlambat saat mengikuti pramuka dengan alasan yang beragam.

Siswa tersebut merupakan siswa pramuka dengan tingkatan Penggalang. Kurang minatnya siswa dalam mengikuti kegiatan wajib pramuka adalah jenuh karena dalam sehari sudah mengikuti mata pelajaran. Oleh karena itu, maka diperlukan adanya pembelajaran yang menarik pada kegiatan wajib pramuka. Sehingga siswa tidak jenuh dan minat siswa terhadap kegiatan wajib pramuka bisa kembali. Kegiatan wajib pramuka ini perlu suatu media penunjang di mana media tersebut dapat membuat siswa tidak jenuh dan mengembalikan minat terhadap kegiatan pramuka yaitu berupa board game. Board game dipilih karena dapat menghilangkan rasa jenuh dan dapat meningkatkan minat belajar. Board game memiliki komponen seperti bidak yang dapat disentuh yang dapat memberi sensasi yang berbeda dengan dipertemukan dengan pemain lainnya yang diharapkan bisa berinteraksi, bekerja sama dan melatih kekompakan dalam menyelesaikan suatu masalah.

\section{Konsep Perancangan}

Tujuan board game pramuka ini adalah membantu siswa dalam pembelajaran kegiatan pramuka serta meningkatkan minat terhadap kegiatan pramuka. Board game sendiri bisa melatih kedisplinan melalui peraturan yang telah disediakan dalam permainan tersebut. dan menumbuhkan rasa sosial dengan cara berinteraksi langsung dengan pemain lainnya.

Sesuai dengan tujuan kreatif, maka perancangan board game pramuka ini memiliki strategi kreatif yaitu menuangkan materi pramuka kedalam permainan board game. Perancangan board game pramuka ini ditujukan untuk siswa sekolah dasar tingkatan penggalang yaitu kelas 5 dan 6 . Dalam board game tersebut membahas materi tentang pramuka yang terdiri dari pengetahuan penggalang dan teknik kepramukaan. Tingkat kesulitan dari permainan ini disesuaikan dengan tingkatan Penggalang sekolah dasar.

Permainan board game ini terdapat 5 tingkatan yang berbeda. Dalam setiap tingkatan terdapat materi yang disesuaikan dengan tingkat kesulitannya. Dalam permainan ini setiap pemain dihadapkan dengan soal-soal tentang pengetahuan dan teknik kepramukaan. Setiap akan naik tingkatan, maka pemain akan dihadapkan dengan materi sandi. Pemain juga dihadapkan dengan pemanfaatan resource yang diberikan yang bertujuan untuk pemain bisa tegas dalam mengambil keputusan.

Permainan board game ini dimainkan secara individu dan berkelompok. Permainan secara individu bertujuan melatih pemain untuk mandiri dalam mengambil keputusan serta melatih keberanian. Permainan secara berkelompok bertujuan melatih kerjasama dan kekompakan serta meningkatkan rasa sosial terhadap antar pemain. Permainan ini bisa dapat membantu dan memudahkan pembina pramuka dalam pengajaran karena memanfaatkan kerja tim sehingga siswa yang belum menguasai materi dapat memahami materi tersebut.

Aspek visual dari permainan board game ini adalah berupa ilustrasi. Ilustrasi menurut Maharsi (2016) merupakan representasi visual dari sebuah naskah, baik itu konsep cerita dalam bentuk gagasan ide ataupun naskah tercetak untuk keperluan tertentu. Menurut Soedarso (2014) bedasarkan penampilannya, gambar ilustrasi memiliki berbagai jenis, yaitu: Ilustrasi Naturalis, Ilustrasi Dekoratif, Ilustrasi Kartun, Ilustrasi Karikatur, Ilustrasi Khayalan. Dalam permainan ini, ilustrasi yang digunakan adalah ilustrasi dengan gaya kartun karena menyesuaikan dengan target audience.

\section{Skenario Permainan}

1. Persiapan Permainan

Sebelum permainan dimulai, ada beberapa peralatan permainan yang harus disiapkan, seperti Papan Peta, Pion, Dadu, Token dan Kartu. Kartu disusun sesuai dengan jenisnya yaitu berupa Kartu Tantangan dengan 5 tingkatan berbeda, Kartu Kejutan, Kartu 
Kejutan, dan Kartu Pembuka Gerbang. Sebelum diletakkan disebelah Papan Peta, kartukartu tersebut diacak terlebih dahulu. Dalam permainan ini, dibutuhkan juga pembina Pramuka sebagai pengawas jalannya permainan agar permainan dapat dijalankan dengan jujur dan menentukan benar atau tidaknya jawaban yang diberikan pemain. Permainan ini dimainkan maksimal 4 orang pemain, serta permainan board game ini bisa dimainkan secara individu ( 1 pemain melawan pemain lainnya) atau secara tim ( 2 pemain melawan 2 pemain).

2. Alat-Alat Permainan

a. Papan Peta

Papan peta digunakan sebagai media utama dalam permainan board game Pramuka ini. Pada papan peta ini terdapat 4 titik yang nantinya akan dijumpai pemain, yaitu: Titik Tantangan, titik di mana pemain mendapatkan kartu tantang yang terdapat materi soal Pramuka Penggalang, Kotak Kejutan yaitu kotak di mana pemain mendapatkan berbagai kejutan yang bisa menguntungkan atau bisa merugikan saat bermain, Titik Berhenti yaitu titik dimana pemain berhenti untuk menyelesaikan soal dari kartu pembuka gerbang guna melanjutkan ke tingkatan selanjutnya, dan Titik Jebakan yaitu titik di mana mendapatkan kondisi buruk saat bermain dan dapat mengakibatkan pengurangan skor.

Pada setiap sisi Papan Peta terdapat 3 kolom kotak, yaitu Clue Bonus, Stamina, dan Kondisi. Kolom Clue Bonus adalah kolom dimana bisa mendapatkan skor tambahan dalam permainan. Dalam satu permainan, hanya terdapat satu rangkaian kata "P-R-AM-U-K-A" yang dapat dirangkai. Huruf-huruf tersebut didapatkan dari Kotak Kejutan yang langka untuk didapatkan. Kolom Stamina digunakan untuk menempatkan stamina pemain. Dalam permainan hanya disediakan 3 stamina setiap pemain dan diharuskan menjaga stamina tersebut agar tidak habis. Kolom Kondisi digunakan untuk memberitahu kondisi pemain saat ini. Jika pada kolom kondisi pemain kosong, maka bisa dikatakan aman. Kartu kondisi diisi dengan mendapatkan kartu jebakan yang berisikan kondisi buruk pemain.

b. Pion

Pion dalam permainan ini tersedia 4 buah pion sesuai maksimal pemain yang memainkan permainan board game Pramuka ini. Setiap pion menggambarkan karakter yang sedang berlari membawa senter. Dalam setiap pion dibedakan oleh warna tas yang dibawa dan alas dari pion tersebut.

c. Dadu

Dadu dalam permainan ini digunakan pemain untuk menentukan langkah yang harus diambil dalam setiap giliran yang didapat.

d. Token

Token dalam permainan ini berupa kartu kecil yang digunakan untuk mengisi kolom yang ada pada setiap sisi Papan Peta. Token tersebut berupa kumpulan huruf "PR-A-M-U-K-A", stamina, dan kondisi buruk yang didapat oleh pemain. Token Stamina merupakan nyawa dari pemain selama bermain board game Pramuka ini. Token Stamina bisa ditukarkan sebagai penambah langkah saat melempar dadu atau menghilangkan 1 kondisi buruk jika pemain membutuhkannya untuk mencegah kekalahan. Token Kondisi Buruk digunakan untuk pemberitahuan jika pemain memiliki kondisi buruk saat bermain. Token Huruf "P-R-A-M-U-K-A" digunakan untuk pemberitahuan jika pemain mendapatkan huruf tersebut. Token ini bisa menambahkan poin pemain jika mendapatkannya. 
e. Kartu Permainan

Kartu dalam permainan board game Pramuka ini terdapat 4 jenis kartu, yaitu:

Kartu Tantangan, merupakan kartu dimana terdapat soal-soal yang memuat materi Pramuka penggalang. Pada kartu tantangan terdapat 2 jenis, yaitu Tantangan Teknik dan Tantangan Pengetahuan. Tantangan Teknik berisi materi tentang teknik kepramukaan dalam Pramuka Penggalang, sedangkan Tantangan Pengetahuan berisi materi tentang pengetahuan seputar Pramuka Penggalang. Pada Kartu tantangan ini dibagi menjadi 5 macam sesuai dengan tingkat kesulitan soal yang diberikan pada kartu tersebut.

Kartu Kejutan, merupakan kartu dimana terdapat berbagai kejutan yang dialami oleh pemain jika mendapatkannya. Kejutan dalam kartu ini bisa berupa kejutan baik atau kejutan buruk. Kartu Jebakan, merupakan kartu di mana terdapat kondisi-kondisi buruk yang dialami pemain jika mendapatkan kartu tersebut. Kondisi tersebut berupa kejadian yang tidak diinginkan oleh siswa Pramuka serta cuaca yang dapat menghambat laju pemain.

Kartu Pembuka Gerbang, merupakan kartu di mana terdapat materi berupa sandi yang harus dipecahkan untuk bisa melanjutkan ke tingkat selanjutnya.

3. Objektif Permainan

Permainan board game Pramuka ini memiliki beberapa objektif yang menjadi target para pemain untuk dapat memenangkan permainan ini, yaitu:

a. Pemenang tidak akan ditentukan berdasarkan siapa yang mencapai titik "Finish" terlebih dahulu, akan tetapi pemenang ditentukan dari berapa banyak poin yang dikumpulkan selama bermain. Poin dihitung dari banyaknya tantangan yang sudah dijawab oleh pemain dan clue bonus yang didapat. Jika pemain masih mempunyai token kondisi buruk, maka kondisi buruk tersebut dapat mengurangi skor yang didapat oleh pemain

b. Pemain yang sudah mencapai titik "Finish" tidak dapat melakukan giliran melempar dadu, akan tetapi menghitung jumlah poin yang telah didapat dengan pengawasan dari pembina Pramuka

c. Pemain dianggap gugur dan kalah apabila Stamina yang dimilikinya habis atau mendapatkan 3 kondisi buruk dalam permainan

d. Apabila pemain sudah mencapai titik "Finish" namun masih membawa kondisi buruk, maka pemain bisa menukarkan dengan poin yang telah didapat $(60$ poin $=1$ kondisi buruk)

4. Alur Permainan

a. Sebelum permainan dimulai, maka setiap pemain mendapatkan 3 token stamina yang diletakkan pada kolom Stamina pada setiap sisi Papan Peta. Kartu-kartu akan diletakkan disisi samping papan peta dan diacak terlebih dahulu

b. Para pemain memainkan dadu terlebih dahulu untuk menentukan siapa yang akan mendapatkan giliran pertama. Setiap giliran selanjutnya, pemain mendapatkan giliran melempar dadu berputar secara arah jarum jam. Setelah melemparkan dadu dan mendapatkan hasilnya, maka pemain menggerakkan pion sesuai hasil yang diperoleh dari dadu. Semua pemain bersiap-siap di titik "Start" sebelum melempar dadu untuk melangkah.

c. Saat pion berhenti di titik Tantangan, maka pemain mengambil kartu Tantangan yang berisikan soal materi Pramuka Penggalang. Jika pemain bisa menjawab soal yang diberikan, maka pemain menyimpan kartu tersebut dalam keadaan terbuka di dekat pemain. Jika pemain tidak bisa menjawab, maka kartu yang diambil tersebut 
dikembalikan ke kartu Tantangan dan diletakkan paling bawah pada kartu Tantangan. Pemain bisa melanjutkan kembali dengan menunggu giliran selanjutnya.

d. Saat pion berhenti di titik Kejutan, maka pemain mengambil kartu Kejutan yang berisikan kejutan yang bisa menguntungkan atau bisa merugikan bagi pemain dengan terdapat perintah pada keterangan kartu tersebut. Kartu tersebut bisa disimpan jika pada kartu tersebut memiliki warna kuning pada background gambar. Kartu tersebut disimpan dan digunakan jika pemain tersebut benar-benar membutuhkan kartu tersebut. Pemain bisa melanjutkan kembali dengan menunggu giliran selanjutnya.

e. Saat pion berhenti di titik Jebakan, maka pemain mengambil kartu Jebakan yang membawa kondisi buruk pada pemain. Pemain yang mendapatkan kartu jebakan, kemudian ditukarkan menjadi token kondisi lalu dipasangkan pada kolom kondisi. Pemain bisa melanjutkan kembali dengan menunggu giliran selanjutnya.

f. Saat pemain ingin meraih titik berhenti, maka pemain melempar dadu sesuai giliran sampai pion yang dijalankan harus benar-benar berhenti pada titik berhenti. Jika pemain mendapatkan hasil dadu yang lebih sesuai target pada titik berhenti, maka pion tersebut berbalik mundur dari titik berhenti hingga pion tersebut berhenti pada titik berhenti sesuai dengan giliran.

g. Saat pion berhenti di titik berhenti, maka pemain mengambil kartu Pembuka Gerbang yang memuat materi Sandi Pramuka. Untuk melanjutkan ke tingkat selanjutnya, maka pemain harus memecahkan sandi tersebut pada kartu Pembuka Gerbang.

h. Saat pion bertemu dengan papan arah "Ganjil" dan "Genap", maka pion tersebut bergerak sesuai lemparan dadu yang diperoleh. Jika saat melempar dadu pemain mendapat angka ganjil, maka pion tersebut bergerak menuju arah yang sesuai pada papan permainan.

i. Selama bermain, Pembina Pramuka mengawasi jalannya permainan dan sebagai penukar poin. Pemain memainkan sesuai giliran yang didapatkannya. Apabila pemain sudah mencapai titik "Finish", maka pemain tidak bisa memainkan dadu lagi dan menghitung poin yang telah didapat dan didampingi oleh Pembina Pramuka.

\section{Poin Permainan}

Poin didapatkan dari berhasil menjawab dari kartu Tantangan dan Clue Bonus jika mendapatkannya. Poin yang didapatkan dari hasil menjawab tantangan mendapatkan 20 poin. Poin tersebut tertulis pada pojok kanan kartu tantangan. Poin yang didapatkan dari Clue Bonus setiap huruf memiliki nilai 100 poin. Poin bisa dihitung menggunakan alat bantu berupa kalkulator atau alat bantu hitung lainnya.

Apabila saat menyentuh titik finish pemain masih mempunyai kondisi buruk, maka pemain harus menukarkan poinnya untuk menghilangkan kondisi buruk tersebut. Poin yang diperoleh bisa ditukarkan kepada Pembina Pramuka dengan menghilangkan 1 kondisi buruk sebanyak 60 poin apabila pemain belum menemukan penawar pada kartu Kejutan atau menghindari dari kekalahan otomatis apabila memiliki 3 kondisi buruk.

\section{Hasil Perancangan}

Sketsa

Proses lanjutan setelah merancang konsep adalah membuat gambaran kasar untuk visualisasi dari papan permainan tersebut. Sketsa yang digambar dalam perancangan ini dimulai dari sketsa karakter, board game hingga papan permainan tersebut.

1. Karakter

Pada board game pramuka ini terdapat dua karakter dengan memakai seragam pramuka lengkap. Karakter ini digunakan dalam kemasan board game dan bidak dalam 
permainan. Karakter tersebut menggunakan gaya ilustrasi kartun yang disesuaikan dengan target audience.

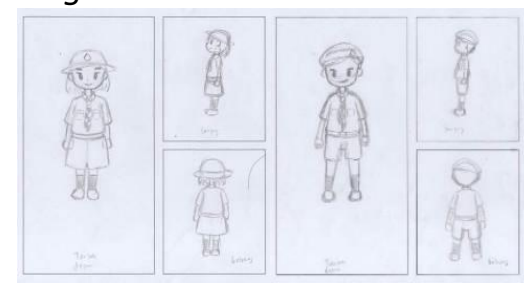

Gambar 1 Sketsa Karakter

2. Papan Peta

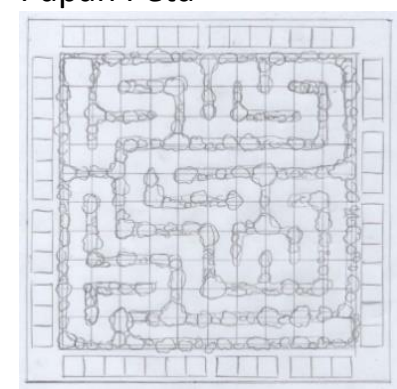

Gambar 2 Sketsa Papan Peta

Papan peta dalam board game pramuka ini adalah media utama dalam permainan. Pada papan peta tersebut menggambarkan suasana hutan dengan terdapat jalan yang rutenya menyerupai seperti labirin.
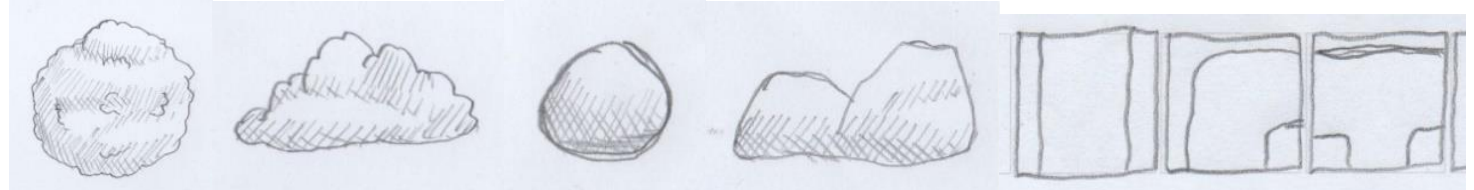

Gambar 3 Sketsa Aset Papan Peta

Papan peta dibuat dari kumpulan beberapa aset yang dibuat menyerupai suasana hutan. Aset tersebut meliputi pohon, semak, batuan, dan potongan jalan. Semua sketsa yang dibuat digambar tampak atas karena mengikuti bentuk papan peta yang datar dan dilihat dari atas. Dibuatnya sketsa terpisah ini bertujuan untuk memudahkan penyusunan papan peta pada saat tahap digitalisasi.

3. Kartu Permainan

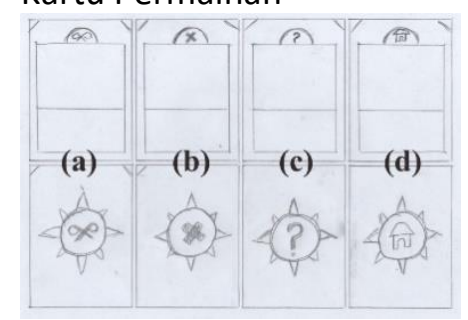

Gambar 4 Sketsa Kartu Permainan

Kartu dalam permainan ini berbentuk persegi panjang yang mempunyai 2 sisi depan dan belakang. Pada sisi depan terdapat kotak gambar yang dijadikan sebagai keterangan gambar dan kotak penjelas berisi keterangan berupa tulisan. Pada sisi belakang terdapat 
ikon yang digunakan untuk membedakan antara kartu lainnya. Pada board game Pramuka ini terdapat 4 jenis kartu, yaitu kartu tantangan (a), kartu jebakan (b), kartu kejutan (?), dan kartu pembuka gerbang (d)

4. Token

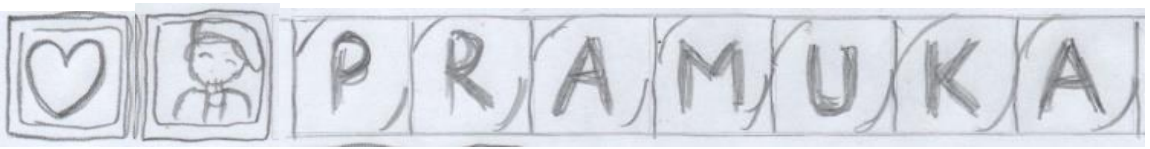

Gambar 5 Sketsa Token Permainan

Token tersebut berupa kumpulan huruf "P-R-A-M-U-K-A", stamina, dan kondisi buruk yang didapat oleh pemain. Token Stamina digunakan sebagai penanda nyawa dalam permainan token ini memiliki bentuk persegi dan terdapat ikon "hati" pada posisi tengah. Token Kondisi digunakan sebagai penanda bahwa pamain memiliki kondisi buruk. Token ini memiliki bentuk persegi dan terdapat gambar karakter yang memiliki kondisi buruk sesuai pada kartu jebakan. Token Huruf "P-R-A-M-U-K-A" digunakan untuk pemberitahuan jika pemain mendapatkan huruf tersebut. Token ini memiliki bentuk persegi dan terdapat hurufhuruf "P-R-A-M-U-K-A" pada setiap tokennya.

5. Pion
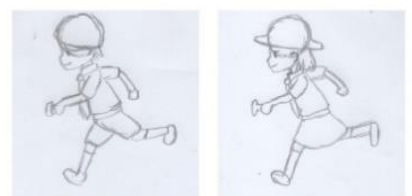

Gambar 6 Sketsa Pion Permainan

Pion dalam permainan ini tersedia 4 buah pion sesuai maksimal pemain yang memainkan permainan board game Pramuka ini. Setiap pion menggambarkan karakter yang sedang berlari membawa senter. Dalam setiap pion dibedakan oleh warna tas yang dibawa dan alas dari pion tersebut.

6. Kemasan

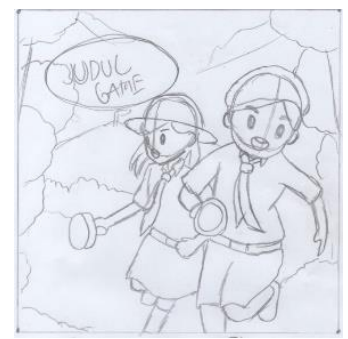

Gambar 7 Sketsa Kemasan Permainan

Kemasan pada board game pramuka ini menampilkan dua karakter yang memakai seragam lengkap untuk menginformasikan bahwa board game tersebut adalah board game pramuka. Latar yang digunakan dalam kemasan tersebut adalah gambar hutan yang menggambarkan suasana petualangan. Senter yang dibawa tersebut ditujukan untuk penerangan pada saat menjelajahi hutan. Judul board game diletakkan pada sisi atas sebelah kiri yang merupakan ruang kosong sehingga tidak menutupi karakter tersebut. 
Warna

Warna yang digunakan dalam karakter board game menggunakan warna dominan coklat. Warna kulit menyesuaikan kondisi kulit orang indonesia yang bewarna coklat sawo matang. Warna coklat tersebut juga digunakan untuk warna seragam pramuka. Warna yang digunakan dalam merancang media board game menggunakan warna yang sesuai dengan warna dalam pramuka. Menurut Yusup and Rustini (2016) terdapat 4 warna utama dalam pramuka yaitu hijau, merah, kuning, dan coklat. Warna hijau yang mengartikan kesegaran hidup, merah yang mengartikan keberanian, kuning yang mengartikan pencerahan hidup, dan coklat yang mengartikan kematangan jiwa.

\section{Tipografi}

Jenis huruf yang digunakan dalam perancangan board game Pramuka ini adalah berjenis Sans Serif. Huruf yang dipilih menyesuaikan karakter siswa Sekolah Dasar yang menyukai hal-hal yang menarik dan lucu serta tetap mudah terbaca dengan jelas. Dalam perancangan ini menggunakan 3 huruf berjenis Sans Serif, antara lain:

1. Dancing Jungle

\section{ABCDEFGHIJKLMNOPORSTUVWXYZ} 1234567890

Gambar 8 Font Dancing Jungle

2. Robaga Rounded abcdefghijklmnopqrstuvwxyz ABCDEFGHIJKLMNOPQRSTUVWXYZ 1234567890

Gambar 9 Font Robaga Rounded

3. Comic Sans

abcdefghijklmnopqrstuvwxyz ABCDEFGHIJKLMNOPQRSTUVWXYZ 1234567890

Gambar 10 Font Comic Sans

\section{Digitalisasi}

Proses digitalisasi adalah proses lanjutan dari tahap pembuatan sketsa. Dalam proses ini terdapat beberapa tahapan dimulai dari digitalisasi karakter hingga papan permainan. Tahapan pertama, sketsa yang sudah dibuat akan di masukkan ke dalam media digital dengan menggunakan alat scanner. Tahapan kedua, hasil sketsa yang telah dimasukkan kedalam media digital kemudian digambar ulang dengan metode tracing menggunakan software Medibang Paint Pro untuk melakukan pewarnaan secara digital. Setelah aset yang dibuat menggunakan Medibang Paint Pro selesai, maka file tersebut akan diubah kedalam format .psd (Adobe Photoshop) dan kemudian dimasukkan ke dalam aplikasi Corel Draw untuk di-layout mulai dari kemasan board game hingga papan permainan. Berikut ini adalah hasil desain final dari board game pramuka:

1. Karakter

Permainan board game pramuka ini memiliki 2 karakter yaitu, laki - laki dan perempuan. Pada karakter tersebut memakai seragam pramuka lengkap. Warna kulit pada karakter tersebut menyesuaikan dengan kulit orang Indonesia berwarna cokelat sawo matang. 


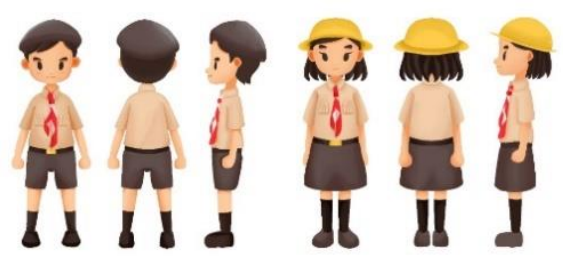

Gambar 11 Karakter Permainan

2. Papan Peta

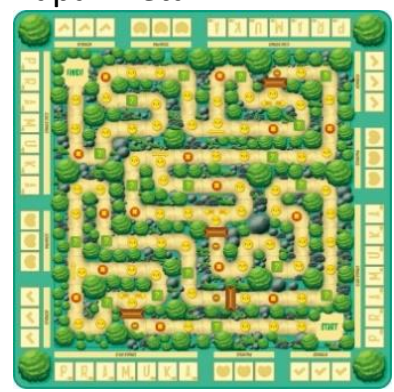

Gambar 12 Papan Permainan

Papan peta memiliki warna dominan hijau karena menggambarkan suasana hutan yang asri. Papan peta tersebut merupakan kumpulan dari jalan, pohon, semak, dan batuan yang disusun menyesuaikan hasil sketsa yang dibuat

3. Kartu Permainan

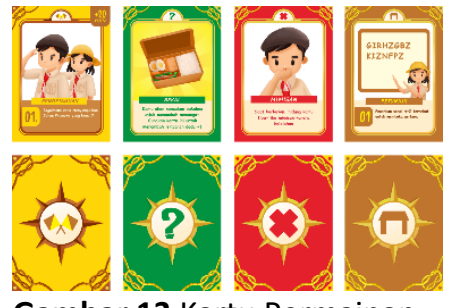

Gambar 13 Kartu Permainan

Kartu permainan board game pramuka ini memiliki 4 macam jenis kartu. Kartu tantangan ditandai dengan warna kuning, kartu kejutan ditandai dengan warna hijau, kartu jebakan ditandai dengan warna merah, dan kartu pembuka gerbang ditandai dengan warna coklat.

4. Token

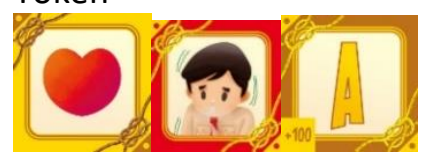

Gambar 14 Token Permainan

Token permainan dalam board game pramuka ini memiliki 3 macam jenis. Token stamina ditandai dengan warna kuning dan terdapat ikon "hati" bewarna merah. Token kondisi ditandai dengan warna merah dan terdapat gambar kondisi pemain yang menyesuaikan pada kartu jebakan. Token clue bonus ditandai dengan warna coklat dan terdapat huruf "P-R-A-M-U-K-A". 
5. Pion

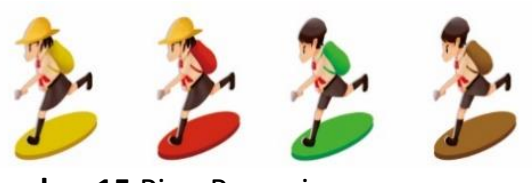

Gambar 15 Pion Permainan

Pion dalam board game pramuka ini terdapat 4 jenis yang dibagi dengan 4 warna berbeda. Pion diambil dari 2 karakter laki-laki dan 2 karakter perempuan. Hal yang membedakan adalah warna tas dan warna alas yang ada pada pion. Warna tersebut meliputi kuning, hijau, merah, dan coklat.

6. Kemasan

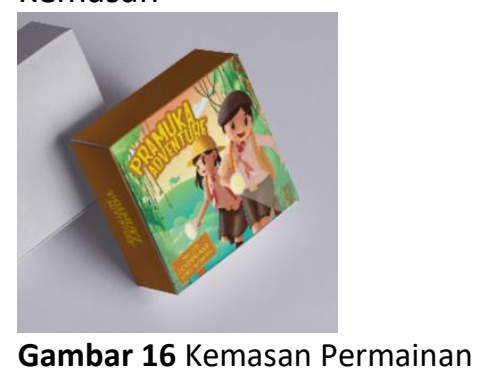

Kemasan board game ini terdapat 2 karakter yang sedang berlari dengan memakai seragam pramuka lengkap. Senter yang digunakan pada karakter tersebut adalah sebagai penerang saat menjelajah. Latar pada kemasan tersebut adalah suasana hutan dengan nuansa warna hijau yang menggambarkan suasana asri dalam hutan tersebut. Judul board game diletakkan pada sisi kiri atas dengan huruf "Dancing Jungle" dan warna yang digunakan adalah warna coklat.

\section{Implementasi}

Selain dari perancangan media utama tersebut perancang juga membuat beberapa media pendukung yang digunakan untuk mendukung media utama permainan ini. Media pendukung tersebut diantaranya adalah guide book, kunci jawaban, $x$-banner, tas ransel, lunch box, kaos, pin, dan rak display.

\section{Simpulan}

Perancangan board game pramuka untuk tingkatan Penggalang siswa Sekolah Dasar yang berjudul "Pramuka Adventure" merupakan board game yang dirancang khusus untuk siswa pramuka tingkatan Penggalang Sekolah Dasar kelas 5 dan 6 yang bertujuan untuk meningkatkan minat terhadap kegiatan pramuka. Board game ini dibuat karena belum adanya media penunjang dalam kegiatan pembelajaran pramuka. Dalam board game ini memuat materimateri seputar Penggalang dari pengetahuan dan teknik kepramukaan.

Board game ini bisa dimainkan dengan cara individu ataupun kelompok. Sehingga pemain bisa bersaing secara sehat dengan pemain lainnya dan bekerjasama dengan pemain lainnya dan bersaing dengan kelompok lainnya. Sehingga selain meningkatkan minat kegiatan pramuka dengan adanya board game ini, maka siswa secara tidak langsung akan terlatih dalam berkomunikasi, meningkatkan rasa sosialisasi, dan kerjasama dengan dipertemukan dengan pemain lainnya. 
Permainan ini cocok dimainkan pada kegiatan pramuka di kelas maupun kegiatan pramuka yang besar seperti perkemahan atau jambore. Permainan ini hanya ditujukan untuk Pramuka tingkatan Penggalang, sehingga masih dapat dikembangkan dengan terdapat versi tingkatan lainnya seperti tingkatan Siaga, Penegak, Pandega, atau Pembina.

\section{Daftar Pustaka}

Burhaein, Erick. 2017. "Aktivitas Fisik Olahraga untuk Pertumbuhan dan Perkembangan Siswa SD." Indonesian Journal of Primary Education 1 (1): 51-58. https://doi.org/10.17509/iipe.v1i1.7497.

Elianta, Peter, Jasson Prestiliano, and T Arie Setiawan. 2019. "Perancangan Board Game sebagai Media Pembelajaran Keselamatan Berkendara untuk Remaja dengan Mekanik Dice Rolling." International Journal of Natural Science and Engineering 2 (3): 80-91. https://ejournal.undiksha.ac.id/index.php/IJNSE/article/view/17186.

Firmansyah, Zuli Agus. 2014. Panduan Resmi Pramuka. Jakarta: WahyuMedia.

Jatmika, Herka Maya. 2005. "Pemanfaatan Media Visual dalam Menunjang Pembelajaran Pendidikan Jasmani di Sekolah Dasar." Jurnal pendidikan jasmani indonesia 3 (1). https://journal.uny.ac.id/index.php/ipji/article/view/6176.

Jordi, Dede, Dini Faisal, and San Ahdi. 2017. "Perancangan Board Game Edukatif Tentang Peduli Lingkungan Untuk Anak Usia 7-12 Tahun." DEKAVE: Jurnal Desain Komunikasi Visual 6 (1): 1-20. http://ejournal.unp.ac.id/index.php/dkv/article/view/8372.

Maharsi, Indiria. 2016. Ilustrasi. Dwi - Quantum.

Mubarok, Mufti. 2008. BCM: Rahasia Cerdas Belajar Sambil Bermain. Surabaya: Java Pustaka.

Nugroho, Eko. 2018. Prinsip-prinsip Menyusun Kuesioner. Malang: Universitas Brawijaya Press.

Rahman, Ridwan Arif, and Dewi Tresnawati. 2016. "Pengembangan Game Edukasi Pengenalan Nama Hewan dan Habitatnya Dalam 3 Bahasa Sebagai Media Pembelajaran Berbasis $\begin{array}{lllll}\text { Multimedia." Jurnal } & \text { Algoritma } & 13 & \text { (1): }\end{array}$ https://doi.org/10.33364/algoritma/v.13-1.184.

Sanyoto, Sadjiman Ebdi. 2006. Metode Perancangan Komunikasi Visual Periklanan. Yogyakarta: Dimensi Press.

Soedarso, Nick. 2014. "Perancangan Buku Ilustrasi Perjalanan Mahapatih Gajah Mada." Humaniora 5 (2): 561-570. https://doi.org/10.21512/humaniora.v5i2.3113.

Sugianto, Vincent Jonathan, WH Prayanto, and Hen Dian Yudani. 2015. "Perancangan Board Game Mengenai Bahaya Radiasi Gadget Terhadap Anak." Jurnal DKV Adiwarna 1 (6): 115. http://publication.petra.ac.id/index.php/dkv/article/view/3173.

Yusup, Jaenudin, and Tini Rustini. 2016. Panduan Wajib Pramuka Superlengkap. Bmedia. 
146 Perancangan Board Game sebagai Media Penunjang untuk Meningkatkan Minat Kegiatan Ekstrakurikuler Pramuka Penggalang Siswa Sekolah Dasar

Ziz, Rizal. 2015. "Yuk Belajar Membuat Board Game: Mengenal Genre Board Game!". Accessed 6 Desember 2019. https://boardgame.id/yuk-belajar-membuat-board-game-mengenalgenre-board-game/. 